\title{
Reproduction of Some Newly Identified Chestnut Genotypes by Different Grafting Methods From West Anatolia
}

\author{
Şemsettin KULAÇ*゚, Yasin ÖZKURU @ \\ Düzce University, Faculty of Forestry, Department of Silviculture, Düzce, TURKEY \\ *Corresponding Author: semsettinkulac@duzce.edu.tr
}

Received Date:22.02.2021

Accepted Date: 26.07 .2021

\begin{abstract}
Aim of study: In the study, the most successful grafting method and chestnut genetypes that are best adapted to the Düzce Kaplandağı chestnut population were tried to be determined.

Area of study: Chestnut seeds used as rootstock material were collected from natural chestnut forests of Kaplandağı, Cumayeri district of Düzce province.

Material and methods: In this study, for the first time identified by us, 20 well-known fruit qualities, two locally known (Serdar and Erfelek), and three foreign (Maraval, Marigoule, and Bethizac) chestnut genotypes were used. It was investigated the success of grafting methods by using 25 different chestnut genotypes and three different grafting methods (budding, the cleft and tongue grafting). The seedlings of the Kaplandağ the rootstock chestnut genotype. The genotypes which were grafted on the rootstock were types of Kabalak, İbrad1, Paşaormanı, Erfelek, Hacı̈̈mer, Serdar, Akçakoca 1, Alaplı 1, Çongara, Fındıklı 1, Gümeli 1, Fındıklı 2, EreğliYazıören, Paşaormanı 2, Gümeli black, Fındıklı 3, Ereğli-Nevzat, Gümeli yellow, Akçakoca yellow, Yığılca-Vedat, Yı̆̆ılca-Çakır, Ibradı 2. and Maraval, Marigoule, Bouche de Bethizac.

Main results: It was determined that stabile temperature and humid conditions affected grafting achievement on chestnut genotypes and grafting techniques. While the lowest grafting success was in the budding, the cleft and tongue grafting methods were the same and have a grafting success rate of $63 \%$. Among the chestnut varieties, the Çongara genotypes (98\%) had the highest while the Findıkl1 2 genotypes (20\%) had the lowest grafting success. As a result, the most successful grafting methods were cleft and tongue grafting, and the most successful grafting genotypes were found as Çongara, İbrad 2 and Alaplı 1. Also, the sapling obtained from the study were taken under ex-situ protection in Düzce University campus as a chestnut orchard.

Highlights: Also, two of them (Pasaormanı and Akçakoca 1) are observed to resist against the gall wasp.
\end{abstract}

Keywords: Chestnut, Castanea sativa, Grafting, Genotype, Ex-Situ Protection

\section{Batı Anadolu'da Yeni Belirlenen Bazı Kestane Genotiplerinin} Farklı Aşılama Yöntemleriyle Çoğaltılması

Öz

Çalışmanın amacı: Çalı̧̧mada en başarılı aşı yöntemi ve Düzce Kaplandağı kestane populasyonuna en iyi uyum sağlayan kestane genotipleri belirlenmeye çalışılmıştır.

Çalışma alanı: Çalışmada anaç materyali olarak kullanılan kestane tohumları Düzce ili Cumayeri ilçesi Kaplandağı doğal kestane ormanlarından toplanmıştır.

Materyal ve yöntem: Bu çalışmada yeni belirlediğimiz meyve kalitesi yüksek 20 genotip, iki lokal çeşit (Serdar ve Erfelek) ve üç yabancı (Maraval, Marigoule ve Bethizac) kestane çeşidi kullanılmıştır. Çalışmada çöğür olarak 2 yaşındaki Kaplandağı popülasyonuna ait yabani fidanlar kullanılmıştır. Bu fidanlar üzerine 25 farklı genotipe (Kabalak, İbradı, Paşaormanı, Erfelek, Hacıömer, Serdar, Akçakoca 1, Alaplı 1, Çongara, Fındıklı 1, Gümeli 1, Fındıklı 2, Ereğli-Yazıören, Paşaormanı 2, Gümeli siyahı, Fındıklı 3, Ereğli-Nevzat, Gümeli sarısı, Akçakoca sarısı, Yığılca-Vedat, Yığılca-Çakır, Ibradı 2., Maraval, Marigoule ve Bouche de Bethizac) ait aşı kalemleri, üç farklı aşı yöntemi (yarma, dilcikli ve yongalı göz) ile aşılanarak aşı başarıları incelenmiş̧tir.

Temel sonuçlar: Sabit sıcaklık ve nem koşulları altında kestane genotiplerinin ve aşılama yöntemlerinin aşı başarısına etkisi belirlenmiştir. En düşük aşı başarısı yongalı göz aşıda (\%55) elde edilirken, en yüksek başarı benzer oranda yarma ve dilcikli aşılarda (\%63) bulunmuştur. Kestane çeşitleri arasında en yüksek aşılama başarısı Çongara genotipinde (\%98), en düşük başarı ise Fındıkl1-2 genotipinde (\%20) elde edilmiştir. Sonuç olarak en başarılı aşılama yöntemleri yarma ve dilcikli aşılar olmuştur. Ayrıca Kaplandağı kestane çöğürlerine en iyi aşı uyumu sağlayan genotipler sırası ile Çongara, İbradı 2 ve Alaplı 1 olarak bulunmuştur. Bu çalışmadan elde edilen aşıll fidanlar, Düzce Üniversitesi kampüsünde materyal bahçesi olarak ex-situ koruma altına alınmıştır.

Araştırma vurguları: Bu genotiplerden ikisinin (Paşaormanı ve Akçakoca 1) gal arısı zararına karşı dirençli olduğu gözlenmiş̧ir.

Anahtar Kelimeler: Kestane, Anadolu Kestanesi, Aş1, Genotip, Ex-Situ Koruma 


\section{Introduction}

Chestnut is an important deciduous temperate forest tree species in the family of Fagaceae (Kremer et al., 2012). Chestnut is one of the natural species of the Mediterranean basin (southern Europe, north of Africa, southwest and east Asia). It is reported that chestnut was taken from Anatolia to southern Europe in the 5th century of $\mathrm{BC}$, then shifting further south from here and extending to the Balkan Peninsula, southern Italy, and France (OGM, 2013) (Figure 1). Although it is known about 10-12 species of the chestnut genus globally, Anatolian chestnut (Castanea sativa Mill.) is the only species naturally occurs in Turkey (FAO, 2019a). It is naturally grown in forests and grafted in orchards for nut production (Camisón et al., 2021). Anatolian chestnut shows a genetic differentiation on drought adaptation to grown various soil moisture level in different regions (Pigliucci et al., 1990). This tree species has a widerounded crown structure, can grow up to 2530 meters and can live up to 1000 years (OGM, 2013).

Anatolian chestnut forms mixture stands with broadleaf species (oak, hornbeam, beech, linden...etc) in the north Anatolia and Marmara region (Huss \& Kahveci, 2009). Even though, it naturally grows up in the Aegean and Mediterranean regions, there is more cultural practices done with chestnut. Chestnut populations mix up with oak, black and red pine in the natural forests of these regions. According to the forest management plan, chestnut forests cover almost 200.399 hectares' areas in Turkey (Kulaç et. al., 2019). In the northern region of Turkey, Anatolian chestnut forests extend between $400 \mathrm{~m}$ to $600 \mathrm{~m}$ of altitude while they extent 1000-1200 m elevation in the west and south Anatolia (OGM, 2013).

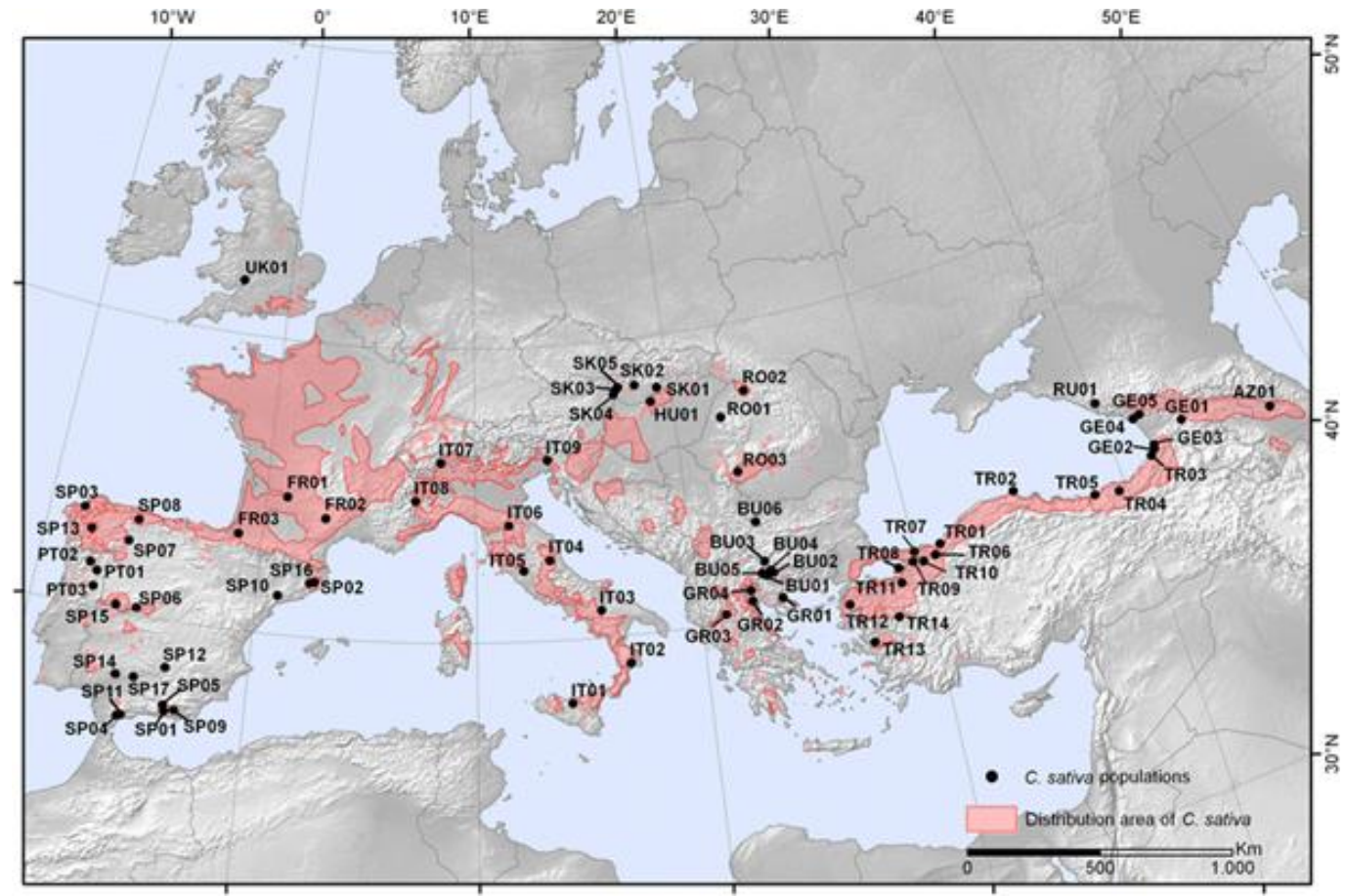

Figure 1. Biogeographic distribution of chestnut (EUFORGEN, 2009)

Anatolian chestnut stands mostly tend to run mix to other broadleaf species and ranked third most after oak and beech (OGM, 2013). According to the data of the world agricultural organization in 2011, approximately 2 million tons of chestnut fruit were produced worldwide. China ranked first place with 1.7 million tons and followed by Turkey with 60 thousand tons of chestnut which was represented about $3 \%$ of world production (FAO, 2019b). According to the General Directorate of Forestry, Turkey's chestnut production has been increased and a total of 70 thousand tons of 
chestnut fruit produced in 2017 (OGM, 2013). However, Turkey moved to 4 th place of chestnut production with this production.

Grafting is the process of creating a genetic clone or copy of an existing tree, and it is one of the most common techniques for stimulating reinvigoration to trees (Hackett \& Murray, 1993; Camisón et al., 2021). The technique means placing a branch from a resistant plant (scion) into another tree or seedling (rootstock). The grafting period grows up with two plants, and then a new plant is created (Keys, 1978). Furthermore, grafting is a more successful and feasible method of layering or rooting cuttings on propagating chestnut (Keys, 1978; Mc Kay \& Jaynes,1969). Incompatibility between the rootstock and scion is the major problem of grafting for the chestnut, and this is observed when the scion does not make an exactly successful union. The proper rootstock choice can eliminate this problem (Keys, 1978). The grafted plant has specific rootstock characteristics like hardiness, drought tolerance, or disease resistance.

Grafting is divided into two parts as budding and scion according to the parts used. Shoot can also be classified into two such as early and late, and stagnant according to the time of grafting (Serdar, 2017). The scion grafting is used in plants that are suitable for budding grafting. It is recommended to have 2-4 buddings on the scion in this type of grafting. Although, there are many types of grafting methods the most preferred grafting methods are a whip, cleft, side, bark, tongue (Serdar, 2017; Altan, 2010; Y1lmaz, 2010). Moreover, there are various grafting methods for Chestnuts, such as British grafting with and without tongues, split grafting, under-shell grafting, and sideshots; Eye grafting methods such as $\mathrm{T}$, inverted $\mathrm{T}$, chipped eyes, patches, and bracelets have been using. The selection of the best grafting methods depends on conducted the effects grafting methods on grafting success (Tokar \& Kovalovsky, 1971; Ertan \& K1lınç, 2005; Şen et. al., 1993). However, a limited number of studies has been done on the adaptation on chestnut genotypes in the world and especially in Turkey. So, in this study, a total of 25 genotypes (22 native and three foreign grafting time, rootstock age, size, developmental status, quality and quantity of cuttings, susceptibility to chestnut cancer, the experience of the grafter, grafting cost, grafting environment, and technical possibility factors play a role (Ertan \& Kılınç, 2005; Ferrini, 1993; Ferrini \& Pisani, 1994; Ridley \& Beaumont, 1999).

Budding grafting is easier and quicker than scion grafting therefore it is considered simple and economical. In budding grafting, leaf or buds on shoot bark are used instead of the scion. Budding grafting method is usually applied during the vegetation period, from spring to autumn, when the back can easily be separated from its wood. The most common used budding methods are $\mathrm{T}$ budding (shield budding), I-budding, reverse T-budding, ring and patch budding and chip budding (Yılmaz, 2010; Aslantaş et. al., 2007; Ayfer, 1981; MEB, 2019). Recently, many researchers not only in Turkey but also around the world stated that the ideal method of chestnut reproduction is grafting. The first and the most important step in the grafting method on chestnut production is the selection of compatible rootstock to scion. The scion is required to become viable, resistant to diseases and high success of grafting. Grafting method and time, the adaptation of genotypes and the grafting environments affect the success of grafting (Serdar, 2017; Balta et. al., 1993; Soylu et al., 1994; Ufuk \& Soylu, 1998; Ertan \& Seferoğlu, 1998; Ertan, 1999).

The first stage of grafted sapling production is to grow seedlings by selecting the appropriate rootstock. In chestnut cultivation, it is desired that the seeds to be used in grafting should be vigorous, homogeneous, with a high germination rate, capable of grafting at the end of the first year, resistant to disease, drought, and compatible in grafting (Ertan \& Seferoğlu, 1998). There are many studies have been genotypes) and three different grafting methods on Kaplandağı (Düzce) rootstock (it is used in Western Black Sea Forest Nurseries) were used to determine the best grafting methods and genotypes which provide the best grafting adaptation to the Kaplandağ1 (Düzce) chestnut rootstock. Specific objectives were (i) to investigate the 
differences in grafting time on genotypes, and (ii) to determine the best genotypes for this region.

\section{Materials and Methods}

Newly Identified Genotypes of Chestnuts

As a result of our observations, 20 genotypes were identified, which were claimed by the local people to be good in terms of fruit quality (size, fruit flavor, and peeling) in Düzce province and its surroundings, located in the northwest Black Sea region. Seeds were obtained from these determined genotypes, and seedlings were produced from these seeds (Figure 2).

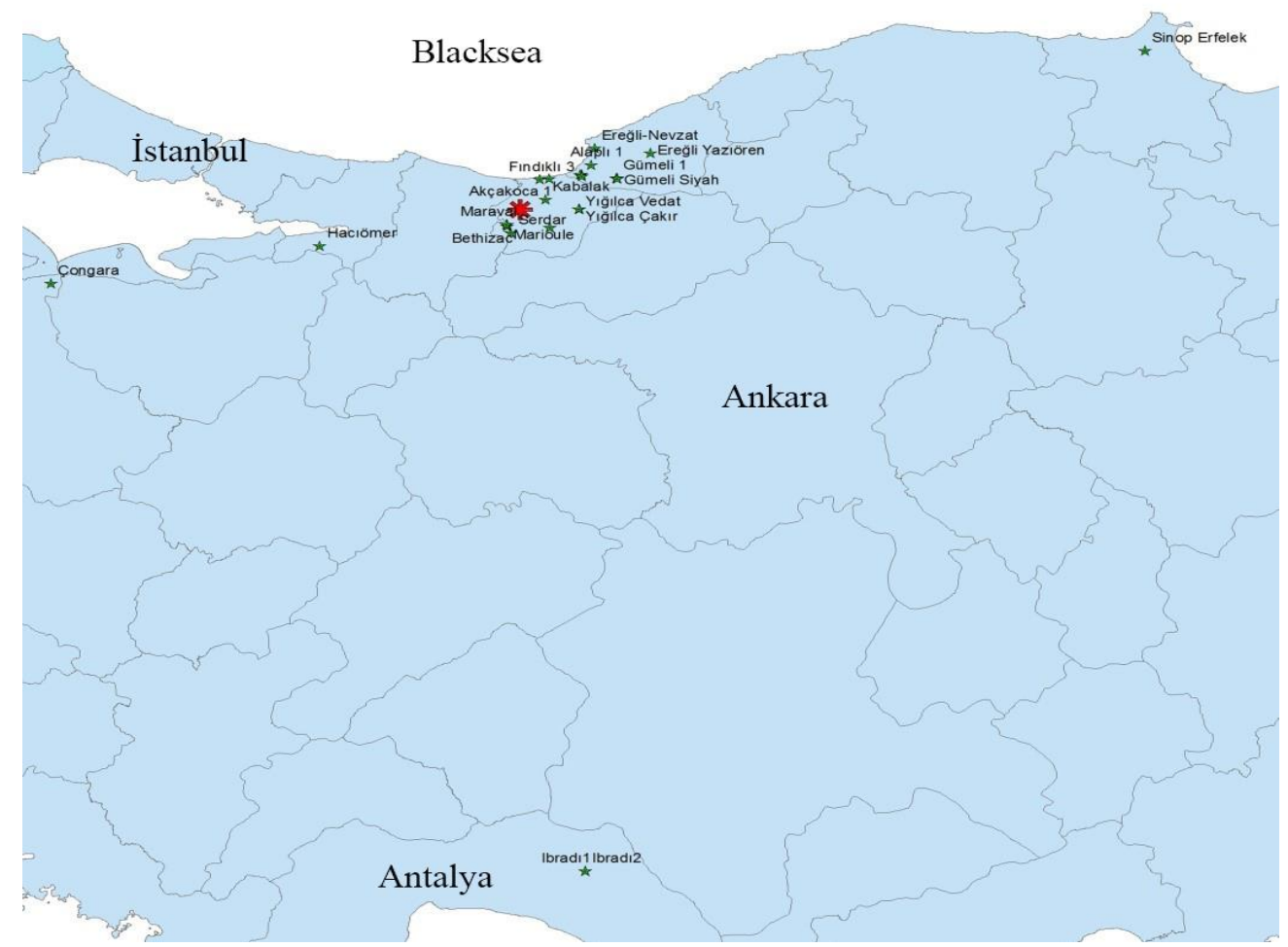

Figure 1. The locations of rootstock and scions used in this study

\section{Seed Germination}

Chestnut seeds were collected from Kaplandağ1 chestnuts forests in Cumaova district of Düzce province. First, these seeds stored at $+2{ }^{\circ} \mathrm{C}$ for two weeks for cold and moist stratification. Then, seeds placed in petri dishes and moved them into the germination chamber $\left(+8{ }^{\circ} \mathrm{C}\right)$ for three to four weeks in the Faculty of Forestry Silviculture laboratory, Düzce University.

When seeds germinated, they were planted in seedbeds in Düzce Pinar Forestry nursery and let them grow two years as rootstocks for this study.

\section{Grafting Methods}

Two-year-old bare root chestnut saplings were grown in Düzce Pinar Forestry nursery and transferred to polyethylene tubes $(18 \times 35$ $\mathrm{cm}$ ) on November 28-30th, 2015. It was used three different grafting methods such as cleft, tongue, and budding on rootstocks on March 2016. Before the grafting practices, the better nut production of chestnut genotypes (newly identified 20 indigenous genotypes, 2 wellknown native genotypes and 3 foreign hybrids) were selected and used as scions. Among native genotypes of scions grafted to rootstocks were used: Kabalak, İbrad,, Paşaormanı, Hacıömer, Akçakoca 1, Alaplı 1, Çongara, Kabalak, Fındıklı 1, Gümeli 1, Fındıklı 2, Ereğli-Yazıören, Paşaormanı 2, Gümeli black, Findıklı 3, Ereğli-Nevzat, Gümeli yellow, Akçakoca yellow, YığılcaVedat, Yığılca-Çakır, Ibradı 2. Serdar, Erfelek, Marigoule, Maraval, and Bouche de Bethizac were used as foreign hybrids of scion. In these genotypes, the minimum and the maximum variation of 1000-seed-weight were 13000-15000 gr, 22000-25000 gr, 
respectively. Also, Paşaormanı and Akçakoca genotypes showed a resistance to the chestnut gall wasp (Drycosmus kuriphilus) in their natural province.

All grafting practices were done in a modern greenhouse condition $\left(20-25{ }^{\circ} \mathrm{C}\right.$ temperature and $60-80 \%$ humidity). The crafted saplings were checked and counted to successfully growing ones on May 2016 to determine the success of the grafting methods.

\section{Experimental Design and Data Analysis}

In this study, three different grafting methods (cleft, tongue, and chip budding) and 25 different genotypes were used, and 20 saplings were assigned for each combination of grafting and genotypes. A total of 1500 saplings were assigned for each grafting method, and a total of 4500 samplings were grafted for this study. We calculated the success of grafting ratio (\%) using the equation below:

Grafting ratio $(\%)=$ successfully grafted seedlings / total number of grafted seedlings (successful and unsuccessful grafted seedlings).

Data were analyzed for mean comparison of grafting methods and genotypes by analysis of variance (ANOVA). Duncan test was used to determine homogenous groups within genotypes (Özdamar, 2004). A level of significance of alpha $=0.05$ was used for inferring any statistical significance. All statistical analyses were performed using SPSS 19.0 statistical package program.

\section{Results}

The genotypes of chestnut scion (G), grafting methods $(\mathrm{M})$, and the interaction of scion genotypes and grafting methods (GxM) were found to be significant $(\mathrm{P}<0.05)$ (Table $1)$.

Budding grafting method had the lowest grafting success ratio $(55.38 \%)$ when cleft and tongue grafting methods had higher ratios $(63.44 \%, 63.33 \%$, respectively) with no statistically significant differences between cleft and tongue grafting methods (Figure 3).

Table 1. Degress of freedom (df), sum of squares (SS), means squares (MS), F values

\begin{tabular}{cccccc}
\hline Source of variation & df & SS & MS & F & P-values \\
\hline Genotypes (G) & 24 & 119734.58 & 4988.941 & 26.645 & 0,000 \\
Grafting methods (M) & 2 & 3202.06 & 1601.030 & 8.551 & 0,000 \\
G x M & 48 & 20334.92 & 423.644 & 2.263 & 0,000 \\
Error & 150 & 28085.22 & 187.235 & & \\
\hline
\end{tabular}

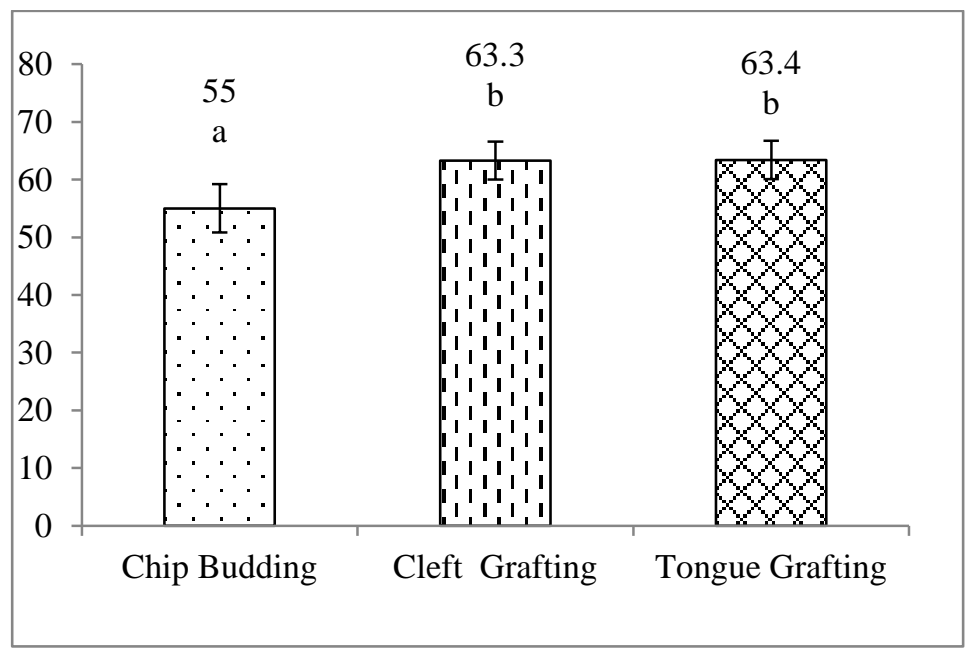

Figure 3. Grafting success ratios of different grafting methods used in this study 
The genotypes of Çongara seedlings had the highest grafting success as $98.43 \%$, followed by the genotypes of İbrad 2 and Alapl1 1 seedlings with the ratios of $93.33 \%$ and $87.90 \%$, respectively while Findikl 2 seedlings had the lowest grafting success ratio (20\%) (Figure 4.).

The interaction of GxM was significant $(\mathrm{P}<0.005)$ on grafting success that the seedlings of Çongara grafting with cleft and tongue methods had the highest grafting success ratio $(100 \%)$. This was followed by cleft and tongue methods in İbrad 12 seedlings (93.3\%). In between budding grafting methods, the genotypes of Çongara and İbradı had the highest grafting success ratios with $95.30 \%$ and $93.33 \%$, respectively. The seedling of Kabalak genotypes had the lowest grafting success $(11.87 \%)$ in the cleft grafting method. However, the seedlings of Findikl 2 genotypes seedlings had the lowest grafting success (20\%) in the tongue method. In general, the lowest grafting success was found in seedlings of Serdar with budding grafting methods (8.9\%) (Table 2).

As a result, Çongara, Ibrad1 2, Alaplı 1, Haciömer, and Erfele were the most successful native grafted genotypes to adapt the rootstock Kaplandağı. Furthermore, Bethizac had the most successful foreign grafted genotypes were followed by Marigoule, and Maraval genotypes that were found to be not good grafting adaptation. In addition, it is recommended to use cleft and/or tongue methods in March due to close results.

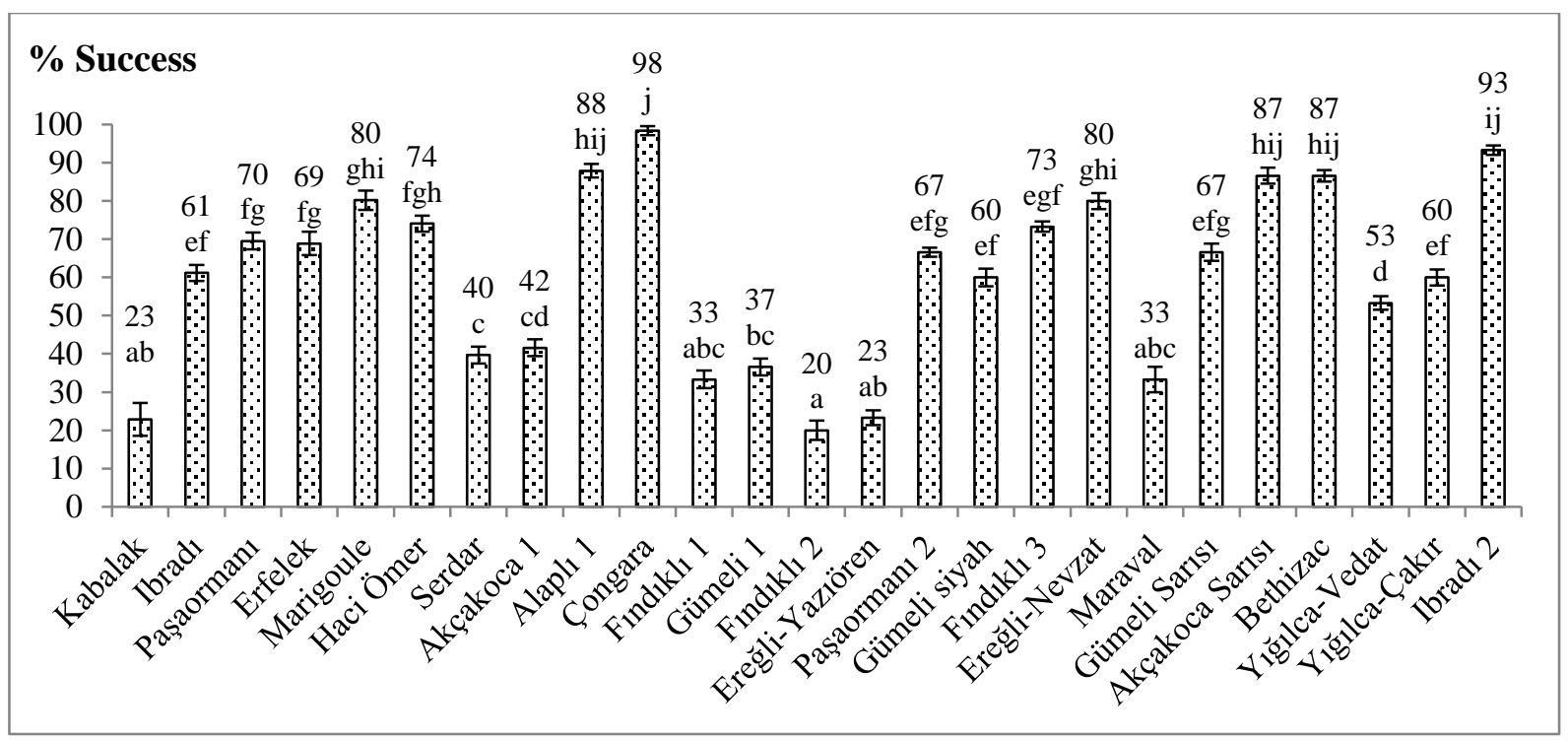

Figure 4. The grafting success ratio of genotypes with Duncan test result 
Table 2. Interaction results of chestnut genotypes by grafting method with Duncan results

\begin{tabular}{|c|c|c|c|c|c|c|c|}
\hline \multirow{2}{*}{$\begin{array}{l}\text { Chestnut } \\
\text { genotypes }\end{array}$} & \multirow{2}{*}{$\begin{array}{c}\text { Grafting } \\
\text { type }\end{array}$} & \multicolumn{2}{|c|}{ Grafting success } & \multirow{2}{*}{ Chestnut varieties } & \multirow{2}{*}{$\begin{array}{c}\text { Grafting } \\
\text { type }\end{array}$} & \multicolumn{2}{|c|}{ Grafting success } \\
\hline & & $\%$ & Groups & & & $\%$ & Groups \\
\hline Serdar & $\mathrm{CB}$ & 8.9 & $\mathrm{a}$ & Paşaormanı 2 & $\mathrm{CB}$ & 66.67 & ghijk \\
\hline Kabalak & $\mathrm{CG}$ & 11.87 & $a b$ & Paşaormanı 2 & $\mathrm{CG}$ & 66.67 & ghijk \\
\hline Akçakoca 1 & $\mathrm{CB}$ & 19.8 & $a b c$ & Paşaormanı 2 & TG & 66.67 & ghijk \\
\hline F1nd1klı 2 & $\mathrm{CB}$ & 20 & $\mathrm{abc}$ & Gümeli Sarıs1 & $\mathrm{CB}$ & 66.67 & ghijk \\
\hline Findiklı 2 & $\mathrm{CG}$ & 20 & $a b c$ & Gümeli Sarıs1 & $\mathrm{CG}$ & 66.67 & ghijk \\
\hline Findiklı 2 & TG & 20 & $\mathrm{abc}$ & Gümeli Sarıs1 & TG & 66.67 & ghijk \\
\hline Ereğli-Yazıören & $\mathrm{CB}$ & 23.33 & $a b c$ & Paşaormanı & $\mathrm{CG}$ & 72.4 & hijkl \\
\hline Ereğli-Yazı̈̈ren & $\mathrm{CG}$ & 23.33 & $a b c$ & Find1kl1 3 & $\mathrm{CB}$ & 73.33 & hijkl \\
\hline Ereğli-Yazı̈̈ren & TG & 23.33 & $a b c$ & Findıklı 3 & $\mathrm{CG}$ & 73.33 & hijkl \\
\hline Kabalak & $\mathrm{CB}$ & 28.43 & abcd & Findikl1 3 & TG & 73.33 & hijkl \\
\hline Kabalak & TG & 28.43 & abcd & Marigoule & TG & 75.17 & ijklm \\
\hline Akçakoca 1 & $\mathrm{TG}$ & 29.87 & abcde & Akçakoca 1 & $\mathrm{CG}$ & 75.17 & ijklm \\
\hline Erfelek & $\mathrm{CB}$ & 31.43 & abcde & Ibrad $_{1}$ & TG & 79.17 & ijklm \\
\hline Findıklı 1 & $\mathrm{CB}$ & 33.33 & abcde & Ereğli-Nevzat & $\mathrm{CB}$ & 80 & $\mathrm{jklm}$ \\
\hline Findiklı 1 & $\mathrm{CG}$ & 33.33 & abcde & Ereğli-Nevzat & $\mathrm{CG}$ & 80 & $\mathrm{jklm}$ \\
\hline Findıklı 1 & TG & 33.33 & abcde & Ereğli-Nevzat & TG & 80 & $\mathrm{jklm}$ \\
\hline Maraval & $\mathrm{CB}$ & 33.33 & abcde & Marigoule & $\mathrm{CB}$ & 80.2 & $\mathrm{jklm}$ \\
\hline Maraval & $\mathrm{CG}$ & 33.33 & abcde & Paşaormanı & TG & 81.17 & $\mathrm{jklm}$ \\
\hline Maraval & TG & 33.33 & abcde & Erfelek & TG & 85.23 & $\mathrm{jklm}$ \\
\hline Gümeli 1 & $\mathrm{CB}$ & 36.67 & bcdef & Marigoule & $\mathrm{CG}$ & 85.23 & $\mathrm{jklm}$ \\
\hline Gümeli 1 & $\mathrm{CG}$ & 36.67 & bcdef & Alapli 1 & $\mathrm{CG}$ & 85.93 & $\mathrm{klm}$ \\
\hline Gümeli 1 & $\mathrm{TG}$ & 36.67 & bcdef & Akçakoca Sarısı & $\mathrm{CB}$ & 86.67 & $\mathrm{Klm}$ \\
\hline Ibradı & $\mathrm{CG}$ & 44.4 & cdefg & Akçakoca Sarısı & $\mathrm{CG}$ & 86.67 & $\mathrm{klm}$ \\
\hline Haci Ömer & $\mathrm{CB}$ & 44.97 & cdefg & Akçakoca Sarısı & TG & 86.67 & $\mathrm{klm}$ \\
\hline Serdar & TG & 50 & defgh & Bethizac & $\mathrm{CB}$ & 86.67 & $\mathrm{klm}$ \\
\hline Y1ğılca-Vedat & $\mathrm{CB}$ & 53.33 & efghi & Bethizac & $\mathrm{CG}$ & 86.67 & $\mathrm{klm}$ \\
\hline Yiğılca-Vedat & $\mathrm{CG}$ & 53.33 & efghi & Bethizac & TG & 86.67 & $\mathrm{klm}$ \\
\hline Yiğılca-Vedat & TG & 53.33 & efghi & Alaplı 1 & $\mathrm{CB}$ & 87.13 & $\mathrm{klm}$ \\
\hline Paşaormanı & $\mathrm{CB}$ & 55.03 & efghi & Haci Ömer & $\mathrm{CG}$ & 87.17 & $\mathrm{klm}$ \\
\hline Gümeli siyah & $\mathrm{CB}$ & 60 & efghij & Erfelek & $\mathrm{CG}$ & 90.27 & $\mathrm{klm}$ \\
\hline Gümeli siyah & $\mathrm{CG}$ & 60 & efghij & Haci Ömer & TG & 90.27 & $\mathrm{klm}$ \\
\hline Gümeli siyah & TG & 60 & efghij & Alapli 1 & TG & 90.63 & $\mathrm{klm}$ \\
\hline Y1ğılca-Çakır & $\mathrm{CB}$ & 60 & efghij & Ibradi 2 & $\mathrm{CB}$ & 93.33 & $\operatorname{lm}$ \\
\hline Y1ğılca-Çakır & $\mathrm{CG}$ & 60 & efghij & Ibrad1 2 & $\mathrm{CG}$ & 93.33 & $\operatorname{lm}$ \\
\hline Yı̆̆ılca-Çakır & TG & 60 & efghij & Ibradı 2 & TG & 93.33 & $\operatorname{lm}$ \\
\hline Ibrad1 & $\mathrm{CB}$ & 60.07 & fghij & Çongara & $\mathrm{CB}$ & 95.5 & $\operatorname{lm}$ \\
\hline Serdar & $\mathrm{CG}$ & 60.27 & fghij & Çongara & $\mathrm{CG}$ & 100 & $\mathrm{~m}$ \\
\hline & & & & Çongara & TG & 100 & $\mathrm{~m}$ \\
\hline
\end{tabular}

$\mathrm{CB}=$ Chip budding, $\mathrm{CG}=\mathrm{Cleft}$ grafting, $\mathrm{TG}=$ Tongue grafting

\section{Discussion}

In this study, we had a grafting success on methods about $63.44 \%, 63.33 \%$, and $55.38 \%$ for the tongue, cleft, and budding, respectively. Under the interaction of GxM, the seedlings of Congara grafting with cleft and tongue methods followed by cleft and tongue methods in İbradi 2 seedlings. However, chestnut splitting, chip eye, lingual, omega, annual bud and patch grafting methods were used in a study that all grafting methods had the highest grafting success (78-80\%) except omega and chip eye (as a green shoot) methods (Pereira-Lorenzo \& Fernandez- Lopez, 1997).

Healthy, desirable rootstocks must be selected on the basis of resistance to disease and high grafting success rates (Ertan \& Seferoğlu, 1998).

Özongun et al, point out that (2004) tongue and splice grafting were the methods recommended for application, while chip budding was not found to be economical. 
A grafting study on chestnut pointed out that the tongue grafting method had the highest grafting success between other grafting methods (cleft, budding, chip eye, and goat toe) in uncontrolled greenhouse conditions (Akyüz \& Serdar, 2017). Another study focused on the 15 Chinese chestnuts (C. mollissima Bl.) cultivars, nine American chestnut [C. dentata (Marsh.) Borkh.] selections, six Japanese chestnuts $(C$. crenata Sieb.) cultivars, and two putative Japanese hybrids on two known rootstocks of Chinese chestnut species (Huang et al., 1994). Their results show that $C$. mollissima intraspecific grafting is more successful than others, and also Chinese chestnut clonal rootstocks could be potential for grafting American and Japanese chestnuts. In addition to chestnut studies, some studies have been done with other species such as walnut, kiwi, and hawthorn. For instance, the tongue grafting method has been chosen in Chandler walnut seedlings after the results of a study due to the highest grafting success ratio (Akyüz \& Serdar, 2017). In the present study, Çongara, Ibradı 2, Alaplı 1, Haciömer, and Erfelek were the most successful native grafted genotypes while the Kabalak genotype was the least successful in adapting Kaplandağ rootstock. The best foreign genotypes, such as Bethizac and Marigoule, successfully adapted to Kaplandagi rootstock in the current study.

Some studies have focused on the success of grafting methods on mango, black mulberry, shea tree, and tallow tree. In a study of mango grafting methods and the success rate depending on grafting time in the Amhara region of the Kalu district in north-eastern Ethiopia, the highest grafting success $(100 \%)$ was achieved in both June and March with the cleft grafting method, while a grafting success rate of $20 \%$ was obtained in January and October using the tongue grafting method (Wubeshet et al., 2019). Another study conducted on the shea tree (Vitellaria paradoxa) found that cleft, tongue, and side grafting methods had $86 \%$, $80 \%$, and $58 \%$ success rates, respectively (Sanou et al., 2004).

The grafting time during the year plays a critical role in the grafting success. The tongue and cleft grafting methods were the most successful in terms of grafting success ratio conducted in March in the current study. A study was conducted in nine of Spanish native chestnut varieties that budding eye, tongue, patch, and cleft grafting methods were used on Spanish hybrid and French CA 15 Marigoule rootstock seedlings at different times to determine the best grafting success period and methods for these species (Aslan, 2019). Tongue grafting methods had the greatest success in March when the highest grafting methods success had on tongue and cleft in this study (Aslan, 2019).

Another study was conducted on the containerized walnut seedlings to determine the success rate of the shoot grafting method in different environments and times of the year in the Black Sea Agricultural Research Institute. The study was carried out an open and shaded greenhouse as a working environment. It was applied 4 different grafting times (March 15, April 5, April 25, and May 15), and 3 grafting methods (budding, tongue, and Mr. Cherney) on walnut seedlings that the highest grafting success rate (91.7-100\%) was obtained on tongue method in the open area (Gümüş, 2000). Similarly, in our study was conducted on similar dates, the tongue and cleft grafting methods were the most successful in terms of grafting success ratio. In a different study, four different varieties (M 36-5, Yalova 1, Yalova 3, and Yalova 4), and three different time (January, February, and March) were used on walnut seedlings to determine the best grafting time and methods between chip budding, budding, tongue, and cleft grafting. The grafting success ratio was the highest in March while the chip budding method was the lowest success ratio between other grafting methods in that study. There was a similar study on kiwi plants pointed out that the greatest grafting success was shown on March 15 on tongue and whip grafting methods (Öztürk \& Yazıcıoğlu, 2015). When the grafting success ratio compared in chestnut and kiwi plants, we conclude that the tongue grafting method was the best grafting method, and the month of March was the best time as a grafting time for these plants. This study in line with another study we mentioned earlier (Aslan, 2019). 


\section{Conclusion}

In conclusion, the chestnut genotype of Congara was the best grafting adaptation on Kaplandağ 1 rootstock followed by the genotypes of Ibradi 2 and Alapli 1. This study suggests using cleft and tongue grafting methods in a controlled greenhouse environment around Düzce province. It is very crucial to determine the better genotypes as scions and grafting methods and periods in different regions on chestnut production. In addition, it has been known that there are well-qualified delicious native genotypes due to the intensive chestnut production in Düzce province. Further studies should focus on the identification and propagation of native varieties of chestnut in Düzce. Also, the preliminary research should be conducted on different growing environments than a natural growing environment such as arid areas in order to be cultured and produced. In addition, the sapling obtained from the study were taken under ex-situ protection by $5 \times 5 \mathrm{~m}$ distance in Düzce University campus as a chestnut orchard for future research.

\section{Ethics Committee Approval}

Not applicable.

\section{Peer-review}

Externally peer-reviewed.

\section{Author Contributions}

Conceptualization: Ş.K., $\quad$ Y.Ö.; Investigation: Ş.K., Y.Ö; Material and Methodology: Ş.K., Y.Ö; Supervision: Ş.K., Y.Ö; Visualization: Ş.K., Y.Ö; WritingOriginal Draft: S..K.; Writing-review \& Editing: Ş.K., Y.Ö; Other: All authors have read and agreed to the published version of manuscript.

\section{Conflict of Interest}

The authors have no conflicts of interest to declare.

\section{Funding}

The authors declared that this study has received no financial support.

\section{References}

Akyüz, B. \& Serdar, Ü. (2017). Tüplü ceviz fidani üretiminde farkli sürgünaşi yöntem ve zamanlarinin aşi başarisina etkisi. Bahçe, 46(Özel Sayı 2), 267-272.

Altan, Y. (2010). Bitki Aşı Teknikleri El Kitabı. Ankara. Tarım Orman ve Köyişleri Bakanlığı Yayınları.

Aslan, D. E. (2019). The effect of different grafting method stografting success in chestnut (Cestanea sativa Mill.). Master thesis, Düzce University, Düzce.

Aslantas, R., Pirlak, L. \& Güleryüz, M. (2007). The nutritional value of wild fruits from the North Eastern Anatolia region of Turkey. Asian Journal of Chemistry, 19(4), 3072.

Ayfer, M. (1981). Ziraat Mühendisliği Bakımından Bitkilerde Aşı-Aşılama Çağlayan Bilim ve Teknik Ansiklopedisi. İstanbul: Çağlayan Kitabevi, 1981.

Balta, F., Karadeniz, T., Tekintas, F. E. \& Sen, S. M. (1993). Investigations on anatomical and histological development of the graft formation in chestnut (Castanea sativa Mill.). Proceedings of the 1st International Congress on Chestnut. Spoleto, Italy, 20-23.

Camisón, Á., Martín, M. Á., Flors, V., SánchezBel, P., Pinto, G., Vivas, M., Rolo, V. \& Solla, A. (2021). Exploring the use of scions and rootstocks from xeric areas to improve drought tolerance in Castanea sativa Miller. Environmental and Experimental Botany, 187, 104467.

Ertan, E. (1999). Investigations on the determination of rootstock characteristics of Aegean Region chestnut (Castanea sativa Mill.) types obtained by selection. PhD. Thesis, Adnan Menderes University., Graduate School of Science, Aydın.

Ertan, E. \& Kılınç S. S. (2005). Seleksiyon ile belirlenmiş kestane genotiplerinin morfolojik, fenolojik ve biyokimyasal özellikleri. Adnan Menderes Üniversitesi Ziraat Fakültesi Dergisi, 2(2), 67-77.

Ertan, E. \& Seferoğlu, H. G. (1998). Kestane çögürü yetiştiriciliğgi. Ege Bölgesi I. Tarım Kongresi, Bildiri Kitab1, 1, 7-14.

EUFORGEN. (2019) Distribution Map of Chestnut (Castanea sativa). Available at: www.euforgen.org. Accessed in: October 27th

FAO. (2019a). Available at: http://www.mfa.gov.tr/birlesmis-milletlergida-ve-tarim-orgutu-_fao_.tr.mfa. Accessed in: October 25th 2019.

FAO. (2019b). Birleşmiş Milletler Gıda Tarım Örgütü Available at: http://www.mfa.gov.tr/birlesmis-milletler- 
gida-ve-tarim-orgutu-_fao_.tr.mfa._ Accessed in: October 20th 2019.

Ferrini, F. (1993). Conoscenze e problemi sulla propagazione vegetativa del castagno. Rivista di Frutticoltura, 12, 43-48.

Ferrini, F. \& Pisani, P. L. (1994). Propagazione, impianto, allevamento e techica colturale del castagno. Rivista di Frutticoltura, 11, 65-74.

Gümüş, E. (2000). A study on the propagation of walnut (Juglans regia L.) with bench grafting. Master thesis, Gaziosmanpaşa University, Graduate School of Science, Tokat.

Hackett, W. P. \& Murray, J. R. (1993). Maturation and rejuvenation in woody species. In Micropropagation of woody plants (pp. 93-105). Dordrecht: Springer.

Huang, H., Norton, J. D., Boyhan, G. E., \& Abrahams, B. R. (1994). Graft compatibility among chestnut (Castanea) species. Journal of the American Society for Horticultural Science, 119(6), 1127-1132.

Huss, J. \& Kahveci, O. (2009).Türkiye'de doğaya yakın yapraklı orman işletmeciliği. Ankara: OGEM-VAKFI.

Keys, R. N. (1978). Prospects for vegetative propagation in the genus Castanea. In Proceedings of the American Chestnut Symposium, West Virginia University, Morgantown, WV.

Kulaç, Ş., Nayir, H. N. \& Özbayram, A. K. (2019). Grafting-Adaptation of Native Chestnut (Castanea Sativa Mill.) Varieties of Düzce to Marigoule $(C$. Sativa $\times C$. Crenata) Hybrid Rootstocks. Proceedings of the International Black Sea Coastline Countries Symposium.

Kremer, A., Abbott, A. G., Carlson, J. E., Manos, P. S., Plomion, C., Sisco, P., Staton, M. E., Ueno, S. \& Vendramin, G. G. (2012). Genomics of Fagaceae. Tree Genetics \& Genomes, 8(3), 583-610.

McKay, J. W., \& Jaynes, R. A. (1969). Chestnuts. Handbook on North American nut trees. Northern Nut Growers' Association, Knoxville, 264-286.

MEB. (2019). Aşı tekniği. Available at: http://megep.meb.gov.tr/mte_program_modul/ moduller.pdf/A\%C5\%9F\%C4\%B1\%20Tekni \%C4\%9Fi. pdf. Accessed in: October $20^{\text {th }}$.

OGM (2013). Kestane eylem planı (2013-2017). Ankara; T.C. Orman Ve Su İşleri Bakanlığı, Orman Genel Müdürlüğü Yayınları.

Özdamar, K. (2004). Paket Programlar ile Istatistiksel Veri Analizi - 1. Ankara. Kaan Kitabevi.

Öztürk, A. \& Yazıcıŏlu, E. (2015). Aşı zamanı ve yöntemlerinin kivide (Actinidia deliciosa,

A. Chev) aşı başarısı ve fidan gelişimine etkileri. Gaziosmanpaşa Üniversitesi Ziraat Fakültesi Dergisi, 32(1), 23-29.

Özongun, Ş., Dolunay, E. M., Öztürk, G., Karakuş, A., Kankaya, A. \& Küden, A. (2004): Elma adaptasyon denemesi I (Sonuç Raporu). Ministry of Agriculture and Rural Affairs, General Directorate of Agricultural Production Development, Eğirdir Horticultural Research Institute. Publishing, (22), 1-54.

Pereira-Lorenzo, S. \& Fernandez-Lopez, J. (1997). Propagation of chestnut cultivars by grafting: methods, rootstocks and plant quality. Journal of Horticultural Science, 72(5), 731-739.

Pigliucci, M., Villani, F. \& Benedettelli, S. (1990). Geographic and climatic factors associated with the spatial structure of gene frequencies in Castanea sativa Mill. from Turkey. Journal of Genetics, 69(3), 141-149.

Ridley, D. \& Beaumont, J. (1999). Propagation. The Australian Chestnut Growers Resource Manuel Section A. Dept. of Natural Resources and Environment (Agri. Victoria). ISBN 0 731143876.

Sanou, H., Kambou, S., Teklehaimanot, Z., Dembélé, M., Yossi, H., Sibidu, S., Lompo, D. \& Jean-Marc, B. (2004). Vegetative Propagation of Vitellaria Paradoxa by Grafting. Agroforestry Systems, 60, 93-99.

Şen, M. T, Balta, F. \& Karadeniz, T. (1993). Propagation By Graft of Chestnut (Castanea Sativa Mill.). Proceedings of the 1st International Congress on Chestnut. Spoleto, Italy.

Serdar, Ü. (2017). Anadolu Kestanesi Orijinli (Castanea sativa Mill.): Ersinop, Erfelek, Ünal, Eryayla ve Serdar, Avrupa X Japon kestanesi melezi: Marigoule çeşitlerinin bazı değerlerinin karşılaştırılması. Ulusal Kastane Çalıştayı (Sunum). 05-08.11.2017, Antalya.

Soylu, A., Ufuk, S. \& Ferhatoğlu, Y. (1994). Marmara Bölgesi kestanelerinin seleksiyon yoluyla 1slahı. Sonuç Raporu, Atatürk Bahçe Kültürleri Araştırma Enstitüsü, Yalova.

Tokar, F. \& Kovalovsky, D. (1971). Grafting of Castanea Sativa in the Open Air. Proceedings of the International Congress on Chestnut, 164-172.

Ufuk, S. \& Soylu, A. (1998). Researches on stock-scion compatibility between some important chestnut cultivars and hybrid rootstocks. Proceedings of the II International Symposium on Chestnut, 494, 223-230.

Wubeshet, B., Melkamu, A. \& Yigzaw, D. (2019). Effect of Grafting Time and Technique on The Success Rate of Grafted Mango (Mangifera indica L.) in Kalu District 
of Amhara Region, North Eastern Ethiopia. Cogent Food \& Agriculture. DOI: https://doi.org/10.1080/23311932.2019.15770 23.

Yilmaz, M. (2010). Bahçe Bitkileri Yetişstirme Tekniği. Adana. Çukurova Üniversitesi Basımevi. 